\title{
A Brief Analysis of the Main Character Philip Marlowe in The Long Goodbye
}

\author{
Ren Baiqian, Tian Chuanmao
}

School of Foreign studies, Yangtze University, Hubei, 434023 PRC China.

Received: 2 Oct 2020; Received in revised form: 10 Nov 2020; Accepted: 15 Nov 2020; Available online: 20 Nov 2020 (C2020 The Author(s). Published by Infogain Publication. This is an open access article under the CC BY license (https://creativecommons.org/licenses/by/4.0/).

\begin{abstract}
This paper is to interpret the main character's image in The Long Goodbye written by Raymond Chandler. It discusses this novel from three perspectives: the main character's characteristics, the relationship between the author and the main character. This thesis points out: the personality of Philip Marlowe was greatly affected by both Raymond Chandler's personal experience and the social circumstance at that time.

In this paper, the author mainly applied "Text Analysis" to interpret the image of Philip Marlowe. The body of this thesis consists of three parts: Part one shows the relationship between Raymond Chandler and Philip Marlowe. He describes himself as "an unbecoming mixture of outward difference and inward arrogance". He was a soldier and experienced World War One. Suffered from miseries and loneliness, he considers himself always living on the edge of nothingness. We can clearly see Raymond Chandler's features from the main character Philip Marlowe.

Part Two gets a deep insight into Philip Marlowe's characteristics. As a detective, Philip Marlowe shows a tough guy image. He is brave and devotes himself to saving others. At the same time, he isolates himself from the busy urban social life, which represents his loneliness.

Part Three analyses deep connotations of the image of Philip Marlowe. From the perspective of the individual, he is the one who saves the people in misery and struggles to achieve his dream; from the perspective of the society, he is a product of the current environment. Under the influence of comprehensive factors, he became a "tough guy" detective.
\end{abstract}

Keywords-Raymond Chandler; Philip Marlowe; Tough guy image; hero worship.

\section{INTRODUCTION}

\subsection{General Introduction to Raymond Chandler and The Long Goodbye}

Raymond Chandler is a famous American detective writer. $\mathrm{He}$ is honored as the founder of hard-boiled detective fiction and has a profound influence on modern fiction. In the past 70 years, his writing style and narrative skill were used as references by later writers.

In 1888, Raymond Chandler was born in Chicago. In 1896, after his parents divorced, he went to London with his mother. In London, he entered Dulwich College for further study. Dulwich College is a public school, and his education experience in there played an important role in the formation of his personality. In 1922, he started to work in an oil company, and he got a great promotion. But 10 years later, he was fired because of excessive drinking. Since then, he decided to focus on writing fiction stories for earning a living. There are many reasons why he chooses to write detective fiction, but the most important reason is that he was aware of his literature dream at that time.

In Raymond Chandler's writing career, he published eight novels in total and a series of short stories. Most of his works are very popular. In 1939, he wrote his first novel The Big Sleep. In this novel, he created the character Philip Marlowe, which later became his salient feature. This book is a landmark in the history of the American detective novel. In 1940, he finished his second novel, Farewell, My Lovely, which caught many writer's eyes. Same with his first novel, the second one set Philip Marlowe as the main character. 
In 1942, he published The High Window, the movie right of which was sold one year later.

Raymond is one of the most prominent writers of the hard-boiled American form and he changed the entire tone of hard-boiled fiction. He created the symbol of the private eye, which is cynical, courageous, sentimental.

The Long Goodbye is Philip Chandler's last important book and is considered as the best book of him. Some critics said that this is his most ambitious novel and also the most autobiographical novel. The Long Goodbye received the Edgar Award for Best Novel in 1955. The title is from the proverb in the novel: "To say goodbye is to die a little". When Philip Marlowe and Terry Lennox were friends, they never say "goodbye", but when Terry Lennox betrayed Marlowe and their friendship, Marlowe said "goodbye" to him peacefully. This novel is actually a study in personal loyalties.

At the heart of this novel is Philip Marlowe's friendship with Terry Lennox, who drifted into Marlowe's personal life. Terry Lennox has a mysterious past. Marlowe meets drunken Terry Lennox in a club. Then they become friends. Lennox married the daughter of a tycoon and he knows clearly that he is little more than a gigolo, but he accepted his marriage and chaotic life. One day, Lennox shows up with a gun in hand. His wife is brutally murdered, and he asks Marlowe to help him escape to Mexico. Marlowe agrees out of friendship rather than loyalty to Lennox as a client.

The next day, Lennox is charged with murdering his wife. No doubt Lennox's action brings Marlowe into an almost inevitable conflict with the police. In jail, he is roughly treated and tortured by the police. He refuses to corporate with the police and he keeps silent during a week in jail. He is pressed to show evidence that would involve both Lennox and him. Later, Marlowe is told that Lennox has committed suicide and the police find his confession in his room. Marlowe is released. He doubts Lennox's suicide but then several people come to him to warn him to suspense the case. Soon Marlowe received a letter and a large sum of money from Lennox. Something seems to be strange.

Lennox's case is over, and no one is allowed to reinvestigate it. One day, Marlowe gets another job to find Roger Wade, who is a writer addicted to alcohol and has been missing for 3 days. After finishing this job, Marlowe is requested to help Roger to stay sober long enough to finish his book. Roger's wife Eileen tells Marlowe that Roger is a dangerous person and once he hurt his wife after drunk. She forge evidence to make Roger and others suspect that Roger murdered Lennox's wife. Then Roger is found dead in his room and all the evidence indicates that he committed suicide after drinking. One day, Marlowe and Roger's agent cone to the Wades. Marlowe debunks Eileen's lies and he indicates that Eileen is the murderer of Lennox's wife and Roger Wade. Terry Lennox's former name is Paul Marston. He is actually Eileen's former husband. But after the war, the disappeared and years later he showed up with a broken body and broken heart. He has changed greatly, and Eileen even cannot recognize him. When Eileen fond that Roger had an affair with Lennox's wife, she killed her out of anger and jealousy. But Terry till loves Eileen at that time, he pretended to flee to escape punishment in order to protect Eileen. The next day, Eileen is committed to suicide and leave a confession. Marlowe asks a journalist to publish Eileen's confession despite others' warnings. He did this as a way to say goodby to his friend Terry Lennox. In the end, a Mexican man comes to visit Marlowe, and he tells the encounter of Lennox in Mexico to Marlowe. Then Marlowe recognizes that he is Lennox who has changed his name and undergone a plastic surgery.

In The Long Goodbye, the business of detection is subordinate to the themes of personal responsibility, betrayal, and the mutability of all human relationships. Chandler intended to shape The Long Goodbye a serious novel first and foremost and a suspense story in the second place. It represents a remarkable transition from the detective novel to the realm of serious fiction, a transition that has subsequently been limited but not equaled.

Although The Long Goodbye is a detective novel, it is full of exploration of human nature and reflection on society. As a detective novel, it points directly to the corruption of the society and arouses people's deep thinking. The hard-boiled detective novels have taken a completely different road from the classical detective novels. It begins to move towards realism and pays more attention to the characterization of the detective's character and narrows the distance between the reader and the detective.

\subsection{Literature Review}

Generally speaking, studies about hard-boiled detective fiction and Raymond Chandler began earlier abroad than at home. Scholars abroad have studied hard-boiled fiction and Raymond Chandler from different perspectives and have reached abundant findings. As for studies about them at home, scholars paid little attention to Raymond Chandler's work and the study is quite limited in a certain few aspects.

\subsubsection{Research on Hard-boiled Detective Fiction}

Hardboiled detective fiction is a literary style, most commonly associated with detective stories, distinguished by the unsentimental description of violence and sex. This 
style was pioneered by Carroll John Daly in the mid-1920s, popularized by Dashiell Hammett over the course of the decade, and refined by Raymond Chandler beginning in the late 1930s.

Thanks to the reform and opening-up in the 1970s, many foreign detective novels were translated into Chinese, which arouses the concern of researchers in China. In the 1990s, some theoretical studies appeared, for example, A History of Popular Fiction (2003) by Huang Lushan. In this book, the origin and the features of hard-boiled detective formula is illustrated, and Raymond Chandler, Dashiell Hammett are considered as representative writers. However, the monographs about hard-boiled detective fiction and Raymond Chandler in China are still few in number.

However, the studies about hard-boiled detective fiction and Raymond Chandler are abundant and illustrated from various perspectives. In the $1940 \mathrm{~s}$, criticism on the hard-boiled detective began to emerge. Murder for Pleasure: The Life and Times of the Detective Story was published by Howard Haycraft. This book introduced the history of detective novels.

At the end of the 1960s, the whole genre was re-evaluated. The most important book was Tough Guy Writers of the Thirties (1968) written by David Madden. In this book, the author gave an introduction to the history of hard-boiled genre as well as the school of writers.

In the 1980s, both the hard-boiled detective fiction and writers are widely received by people, and they also made great progress in literature. Next year, Dennis Porter published The Pursuit of Crime: Art and ideology in Detective Fiction, which illustrated the ideological structure of hard-boiled fiction. In the meantime, more and more scholars attempted to analyze the whole genre.

In recent years, the hard-boiled fiction has become more and more popular all over the world. Consequently, the research on this field became more internationalized than ever before. Diversified perspectives have been applied in the researches, such as cross-cultural comparison, genre, feminist, reader response. Nowadays, hard-boiled detective fictions are widely accepted by people, and it is no longer sub-literature in literary theoreticians' mind.

\subsubsection{Research on Raymond Chandler}

There is still a huge gap in research status between at home and abroad. In domestic research, scholars laid emphasis on the social connotation and influence, neglecting the tough guy image in his novels.

In China, little research has been done on Raymond Chandler even though his novels had been introduced into China a long time ago. The great Chinese writer Qian
Zhongshu adores his books very much and he recommended them to Chinese readers. Decades ago, Raymond Chandler's The Little Sister was introduced into China, and then 5 novels of him were published in China. But pitifully, his most famous novel The Long Goodbye did not published in a long period. In 2008, all his novels were published in China.

There is still a huge gap between research in domestic and abroad both in depth and width. Yang Jincai, a distinguished scholar at Nanjing University, illustrated Raymond Chandler's writing systematically in Literary History of The United States. In this book, he gave us a general introduction to the hard-boiled detective fiction of Raymond Chandler. In a master's thesis of Gu Liming The Narrative Art of Farewell, my lovely by Raymond Chandler, the author analyzed the narrative art of the novel under the theory of narratology. In general, the research on Raymond Chandler is still at an early stage. And there is still much research space in this area.

Raymond Chandler enjoys great popularity in America owing to his novels. It is said that the famous Japanese writer Haruki Murakami loves Chandler's novel very much and he read The Long Goodbye for 12 times and he even wrote a 20000-word recommendation for this novel. Maugham also praised Raymond Chandler's works and he thought no one can surpass the achievements made by Raymond Chandler. In Charles Scruggs's thesis The Lawn Jockey and "The Justice We Dream Of: History and Race in Raymond Chandler's The High Window, the author analyzed the description of American history and racialism. In Raymond Chandler and the Art of "the Shakespearean Touch", Joseph Navitsky discussed the writing style of Raymond Chandler. In Lee Spinks's Except for Law: Raymond Chandler, James Ellroy, and the Politics of Exception, the author illustrated Raymond Chandler's works from the perspective of law and politics.

\subsection{Objectives and Significance}

In order to make a comprehensive analysis of the main character Philip Marlowe in The Long Goodbye, the thesis intended to focus on the following questions:

Who is Raymond Chandler and what has he done in his writing career?

What is hard-boiled detective fiction and what are the main features of it?

What are Philip Marlowe's characteristics?

Explore the relationship between Raymond Chandler and Philip Marlowe.

What influenced Raymond Chandler and how he created the image of Philip Marlowe? 
By answering the above questions, the thesis will present an all-around analysis of the characteristics of Philip Marlowe. And then the thesis will figure out the reasons for the formula of his characteristics from the perspectives of the character himself and the social circumstances as well as the author's personal experiences. Besides, it will serve as an enlightenment for further study on Raymond Chandler and his works. So it is significant for people to change their viewpoints toward the so-called "low brow" culture and it also provided a useful method for those who are studying the hard-boiled detective genre.

\section{RAYMOND CHANDLER AND PHILIP MARLOWE}

\subsection{Background}

\subsubsection{Social Background}

The World War I broke out in 1914. Then the entire Europe was overwhelmed by a tense atmosphere. The imperialist countries wanted to carve up the world, but they covered up their evil intentions with nationalism and patriotism. With boiling fight blood, many people joined the army to fight for their own country. During the war, these boys were shaped to be iron-like inflexible, strong minded and fearless. Facing with death courageously and rushing into the battlefield, they were definitely heroes in the war. But when the war ended, they were abandoned by the whole society. They find it hard to fit in normal life and have to make a fresh start to make a living.

When these tough guys returned from the battlefield, they all faced an identity crisis. They were considered heroes and welcomed by the whole nation during the wartime and they were proud of themselves. However, they were ignored by the society after the war. Their heroic identities were gone, and they finally became burdens of the society. They felt traumatized by the great change. They couldn't find proper jobs, realize self-fulfillment. There is no cruel war in normal life, therefore, there is no place for them to sacrifice themselves. Pitifully, they didn't have any other ability except fighting a battle. Some people were both physically and psychologically harmed so that they even couldn't fit into and return to normal life. They were abandoned by the society and could hardly find the meaning of their existence. They became a group of people without identity and normal life. With the war came to an end, the pursuit of the heroism complex disappeared. What these tough guys felt was only loneliness and indifference.

\subsubsection{Background on Raymond Chandler}

Raymond Chandler grew up in England. His father was addicted to excessive drinking, which made him resent his father, and he even said that he would not forgive his father in his whole life. However, he was also addicted to alcohol. He even lost his job for excessive drinking, but he could not be free from the satisfaction and stimulation brought by alcohol.

The war made him reconsider his life. Raymond Chandler came to the U.S.A at 1912, two years later, the World War I broke out. At that time, the young Chandler enlisted in Canadian Corps and was sent to the frontier. The experience in the army influenced and changed him a lot. Once a time, his unit was surrounded and severely attacked by the German army. In the attack, all his comrades-in-arms died in the war and he came back alone safe and sound. He was so deeply struck by his comrade-in-arms' encounter that he said nothing of his experience in the army in his whole life. The war left him with a feeling of deep hurt and also provided him a lot of writing materials which made his writing vivid and attractive. After the war, he lived in California. Like most of the tough guys fought the war, Raymond Chandler experienced all kinds of hardships but gained nothing. These tough guys fought for their country and some of them even sacrificed their lives, but they did not receive any honor for their braveness and patriotism. Raymond Chandler's marriage was also full of tragic color. When he was young, he fell in love with a married woman Cissy Pascal. After Cissy Pascal got divorced from her former husband, they planned to get married but his mother sharply against this marriage. In 1924, chandler's mother died. Not long later, they got married. Then he found that his wife was 18 years elder than him. With time going by, his wife became old. Therefore, Raymond Chandler felt regret for his choice. He indulged himself in alcohol and even had an affair in his company, then he was fired for his conduct. Even so, he felt deep sorrow when Cissy died. He said that the biggest regret was that he did not write a book as a present for his wife. As a result, he became more addicted to alcohol, his word became less, and he could hardly return to his golden age of writing. In 1955, he could not bear the loneliness and desperation, so he committed to suicide and he shot on himself, but only hit the bathtub. Four years later, he died, alone. After he had died, his publishing agent and secretary fought on the copyright of his books. His body was buried in a grave prepared for poor people. Only 17 people attended his funeral. On his headstone were written a few words: "dead men are heavier than broken hearts".

\subsection{Raymond Chandler and Philip Marlowe}

In The Long Goodbye, sometimes we can see some features of Raymond Chandler from the characters. Chandler has much in common with Roger Wade. Therefore, when Marlowe communicate with Roger, he is 
actually communicating with Chandler. In this way, Chandler gets the access to see the inside of himself. We often heard this saying: "art comes from life, but dramatizes life", writing is like this. Writing is actually a reflection of the author's personal experience. For example, Chandler devoted lavish paragraphs to alcohol, gun, fight and murder, which were all come from Chandler's personal experience. He was severely addicted to alcohol, so he had a deep insight into the psychological characteristics of heavy drinkers. He was sent to the front of battlefield and was emotionally traumatized, so he could describe the brutal war truly. In his whole life, he witnessed the killing, touched blood, experienced betrayal and saw his beloved wife died in front of him. His life experiences are indeed wonderful materials for the novel. In fact, he did apply his personal experiences in his novels.

As I mentioned above, Roger Wade has much in common with Raymond Chandler. There are evidences that can approve it.

Firstly, Roger Wade is a famous writer and his books are welcomed by people. But at the same time, his books also received much criticism. From their point of view, all Roger has written are third-rate books and at the bottom of the literature. There are many descriptions of sex and violence, many of which are for catering to the lowest taste. That is exactly why Marlowe once called Roger "a literary prostitute". Roger said that he even does not want to read his books again because he feels it disgusting. Raymond Chandler also wrote articles for magazines. He worked in magazines just for living. In this place, they just focus on quantity rather than quality. So, Chandler wrote at a breakneck speed, which is definitely a bad writing experience.

Secondly, Roger Wade is severely addicted to alcohol which always clouds his mind and bound his tongue. The things that happen in his life make him full of disappointment, therefore, the drink may be the best way for him to face the reality. Raymond Chandler had an abusive, alcoholic father and he resent him. Chandler's father abandoned him and his mother because of alcohol, so he said that he will not forgive his father. But he himself also became physically dependent on alcohol and overwhelmingly involved in getting and using it. He was greatly troubled by alcohol: he lost his job because of it and he even tried to commit to suicide after drinking too much, in addition, he was tipsy everyday after his beloved wife died.

Thirdly, like Roger Wade, Chandler had a lovely soul. At this point, Marlowe is also the same. Lonely people understand lonely people better, that is why Marlowe willing to help Roger. There are few people who truly understand them, therefore, writing and drinking are the best ways for them to express emotions.

Perhaps it is because of the similarities between Roger Wade and Chandler, Marlowe paid much attention to Roger and tried his best to help him and felt regret for Roger's death even though he never said that he likes Roger Wade. When he suspects the reason for Roger's death, he put much effort to investigate it. And he also published the confessions despite of the menace he received. This is not only for Terry Lennox but also for Roger.

The characterization of Philip Marlowe is actually a kind of self-redemption of Raymond Chandler. When Chandler describes Philip Marlowe, he is in fact communicating with himself. In the workplace, Chandler have a very tough way of doing things. He never tolerates cheaters and he will punish them by any kind of means. At the same time, he shows his sympathy to the honest people, such as an honest banker who went to jail for making unsecured loans. Chandler always sticks up to the underdog. Thus, moral integrity and uprightness became the core of Philip Marlowe's character.

If it were not for his drinking, absenteeism and bad relationships with others, chandler would probably have stayed in this seat until he retired, with a generous pension, and become a perfectly ordinary old American, just plain old. Yet he was destined to be another character. Before the age of 43 , the social experiences gave chandler a profound realistic critical perspective. He is not a writer in the study. What's more, he never made peace with the world after his ups and downs in the business world. So, when he began to write, everything in Los Angeles flowed out, sunny gardens, fierce eyes hiding behind curtains, highly capitalized city, bright and down, rank and fashion, police, hooligans, women...

Marlowe's prototype may be chandler's own ideal avatar. Chandler says of Marlowe: "if there are enough people like him, the world won't become too boring to live in." This tough guy likes to sneer and satirize, although he is not as clever as Sherlock Holmes, he never gives up his desire for justice in the face of dirty and evil things. Marlowe is the knight of the dirty street, so chandler is the poet laureate of the crime novel. They are in the dirty environment, and in the pursuit of their own inner justice and ideals. Marlowe once said, "If I was not hard, I would not be alive. If I could not ever be gentle, I would not deserve to be alive."

\section{PHILIP MARLOWE'S CHARACTERISTICS}


Raymond Chandler wrote a series of novels central on Philip Marlowe. In fact, Marlowe is an ordinary person. He has a lonely soul and a simple life. He put all his energy on his work and he even said that a really good detective never gets married. All in all, he is an ordinary man with unyielding will power. He dares to challenge his fate manfully without fear for danger and difficulties and strive to keep dignity as a man.

\subsection{Image of Loneliness}

If we read the whole story about Philip Marlowe, it is not hard to find that he is a lonely individual, wounded either physically and emotionally. His parents both died, and he does not have any brother or sister. He is alone in this city, with no close friends.

Unlike Holmes, who has a partner, Watson, Marlowe is a loner. He is a loner in the city. Like the cowboy, he was an outsider_alone, pure, motivated by personal ideals. And those ideals imply the moral judgment about America's decadence. He is alone in every case he deals with, accompanied by loneliness and murder after murder. He describes the world in his mind this way: "You have to get used to a paler set of colors, a quieter lot of sounds. You have to allow for relapses. All the people you used to know well will get to be just a little strange. You won't even like most of them, and they won't like you too well(Chandler, Raymond. The Long Goodbye[M]. New York:Knopf,2002)". These were the words he used to persuade Terry to quit drinking. In his world, the relationship between people seems close, but very distant; the contact between people seems very intimate but very cold. Although Marlowe is a hard-boiled detective, he has helped drunken terry many times, even when he was a disheveled tramp and often get drunk. It makes one wonder whether the coldness of his heart is his nature or a tool for adapting to the world and protecting himself.

Chandler seems to have intended to shape Marlowe to be a loner, who savoring solitude in the midst of a thrilling crime. However, in the process of solving a case, Marlowe often starts with the determination to win but ends up with a sense of loss.

When Marlowe first met Terry, Terry was drunk and out of sorts. But Marlowe, out of kindness, took him home. Terry came into his life in this way. Although terry is down and out, there is something about him that appeals to Marlowe."I drove home chewing my lip. I'm supposed to be tough but there was something about the guy that got me. I didn't know what it was unless it was the white hair and the scarred face and the clear voice and the politeness. Maybe that was enough. There was no reason why I should ever see him again. He was just a lost dog, like the girl
said(Chandler, Raymond. The Long Goodbye[M]. New York:Knopf,2002)". When terry was in trouble, he chose to trust terry because he believed in their friendship. So, he helps terry escape and keeps silent under the torture of the police. When he learned of terry's suicide, he investigates every detail alone, and in the process, no one really helps him. His long goodbye to terry came when, despite the threat, he released the confessions to the public and eventually cleared Terry of any wrongdoing. When he finally found out that terry had lied to him, he simply said so: "You bought a lot of me, Terry. For a smile and a nod and a wave of the hand and a few quiet drinks in a quiet bar here and there. It was nice while it lasted. So long, amigo. I won't say goodbye. I said it to you when it meant something. I said it when it was sad and lonely and final(Chandler, Raymond. The Long Goodbye[M]. New York:Knopf,2002)". Terry did not die, but Marlowe lost a friend. It was his first disappointment.

The second loss was the Roger incident. He was invited to search for Roger, and when he found him, he was asked to help Roger for a while so that he could write quietly. Roger's sense of quiet and abjection seemed to attract him. Roger once said, "All writers are punks and I am one of the punkiest(Chandler, Raymond. The Long Goodbye[M]. New York:Knopf,2002)". Although he never said he likes Roger, he does take him seriously. While looking after Roger, he discovered some clues. He found that Roger was not so cruel as his wife had described, nor so cruel as others had said. Just when he thought he could save Roger, Roger was killed by his wife. He felt regret for it. He was so disappointed, and he said, "I was looking at life through the mists of a hangover(Chandler, Raymond. The Long Goodbye[M]. New York:Knopf,2002)".

He was alone in his struggle against authority. When a case came up, everyone told him to stay out of it, but he didn't. He refused to cooperate with the police, but to investigate the truth on his own. And sometimes he even ignored death threats.

He was also lonely in his life. He was alone, and no one understood him. He was surrounded by beautiful women, but he made it clear that he thought women would make him sick. He was attracted by many beautiful women, but due to his professional ethics, he did not spend too much time on love. His values are different from those of the police, who in the novel just want to get the job done and have to submit to authority. Marlowe, on the other hand, has always adhered to his own principles, and what he pursues is his inner justice, rather than the law being manipulated by the rich and powerful.

Therefore, it is easy to understand Marlowe's 
loneliness. He had few friends and a clean private life. At the end of each case, he was still alone. Marlowe was somewhat out of tune with the society and even felt alienated from it. Moreover, this is not a special case of Marlowe, almost all of the tough detective were mentally lonely, alienated, cold and cynical. American society is divided into two camps, either acting as a parasite on the dark side or acting for justice without fear of danger. But it is bound to be a lonely road. No friends, no supporters, the only person you can rely on and trust is yourself. Therefore, "loneliness" can be said to be a kind of common character of all tough detectives.

For a person who pursues the ideal life of truth, kindness and beauty, solitude makes him experience deeply and wisely the better life. That is Philip Marlowe, the lonely hunker-down type.

\subsection{Image of tough guy}

As a tough detective, he is never discouraged, as the pressure can never repelhim. We can learn a lot of valuable spirits from him, such as the courage to fight against authority, no afraid of violence, adherence to his own principles under great pressure. These all make up a popular detective.

\subsubsection{Dare to fight against authority}

As a detective, Marlowe, though well versed in the law, did not care about the law or believe in it at all. He saw with his own eyes the extravagance of the rich and their arbitrary manipulation of the law. He was just an ordinary man who played a small part in this world. But his spiritual power was enormous enough to lift up the world.

He dared to fight against authority. This is mainly in two aspects, the first is fighting against the police and the law, the second is against the social consortium.

Marlowe suffered a lot in prison when Terry was wanted. The police looked down on him, thinking he was just a cheapie. The police humiliated him mentally and hurt him physically, and he never gave in. Terry is considered as a murder suspect, and Marlowe, who helps terry escape, is undoubtedly an accomplice. He could have told police that Terry had gone to Mexico, but he held his tongue and said nothing against him. When he dealt with Roger, he was aware of the connection between Roger and Terry, but he did not tell the police. Because the police just want to finish the job, and Marlowe wants justice. He was in danger of being murdered at any moment, but he did not flinch. The difference in his values with the police prevented him from cooperating with them, because the police might back down, and he wouldn't.

Social consortium means power. As Porter says, we live in a so-called democracy where the majority rules over the minority. A good idea, if only it worked. People vote, but the party machine nominates candidates, and the effective functioning of the party machine depends on how much they spend. The money has to come from someone, whether it is an individual or a consortium or a chamber of commerce or some other organization, who expects something in return. What people like me and I expect is to be allowed to enjoy a decent life of privacy. I own several newspapers, but I don't like them, and in my view, they are forever threatening what little privacy we have left. The freedom of the press they are always clamoring for, with a few honorable exceptions, is the freedom to peddle scandal, crime, sex, sensationalism, hate, and innuendo, and the freedom of politics and money to use propaganda tools. The newspaper business makes money from advertising. Advertising revenue depends on circulation, and we all know what circulation depends on. In such a society, there is something special about money. When the amount is large, the money will have its own life and even its own moral code. The power of money can be hard to control. That is why Marlowe's investigations have been dogged. He was repeatedly threatened and told that the investigation must be suspended. But he continues to serve his clients and seek for justice. He risked his life to defend the reputations of Terry and Roger by publishing the confession in a newspaper.

\subsubsection{No fear of violence}

"So passed a day in the life of a P.I. Not exactly a typical day but not totally untypical either. What makes a man stay with it nobody knows. You don't get rich, you don't often have much fun. Sometimes you get beaten up or shot at or tossed into the jailhouse. Once in a long while you get dead. Every other month you decide to give it up and find some sensible occupation while you can still walk without shaking your head. Then the door buzzer rings and you open the inner door to the waiting room and there stands anew face with a new problem, a new load of grief, and a small piece of money(Chandler, Raymond. The Long Goodbye[M]. New York:Knopf,2002)”.

This is his private investigator's life. There is always violence happens to him, and he had nowhere to hide. He thought about giving up the job, but he couldn't give up his responsibility to the society. Perhaps violence was normal to him, and he was not afraid of the threat of violence. He went in and out of the police station, black and blue every time, but his heart was still strong.

After he went to jail because of Terry, he was beaten by the police. After he published the confession, he was beaten by the gang. He responds to violence with violence, 
but never counts on violence. Even in a dirty world, he yearned for the light inside.

\subsubsection{Stick to his principles under pressure}

As mentioned above, what Marlowe sticks to is not the law, but the principles in his mind. As a detective, Marlowe faces tough challenges every day, bull-fighting, bodies, blood and the evil world. Marlowe was also familiar with the evils of human nature. But at all times he was able to maintain proper dignity and be a spiritual winner. In other words, he saw dignity as the most important thing in the world. It makes us very aware of the meaning and significance of life.

The contrast between the characters in this novel is very sharp. The police have the power, Porter has the money, the power, the press, and Marlowe has none. He was always called a cheapie because they thought a hundred dollars would buy his loyalty. In the course of his investigation, he was always confronted with various obstructions.

When terry was declared to have committed suicide, everyone told Marlowe that the case was over, and the news was suppressed. He received multiple threats of suspension from the police, the gang and Porter. They pressed Marlowe in different ways, but in the end, they could not bring him to his knees.

Marlowe is like a fearless knight born in the dark, fighting for honor and compassion. Marlowe was the knight of his time, destined to save the masses. He moves back and forth between civilization and barbarism, between the upper classes and the masses in search of the righteous. Often surrounded by violence and haunted by the harsh urban environment, Marlowe did not give up his pursuit of morality and justice. There is no doubt that Marlowe is a knight with a golden heart who will get into trouble but never give up. Marlowe had few friends, but what he did for his client was what a friend would do.

Private investigators are often both good and evil so that they can walk freely in the gray areas of the city. Marlowe is brave. He is a real tough guy. On the other hand, he is tender, and he is always sympathetic to the weak. He was determined, too, to stick to his principles in a dirty city. $\mathrm{He}$ is the new individualistic hero who can always realize his social value and seek common interests.

\section{DEEP CONNOTATIONS OF THE IMAGE OF PHILIP MARLOWE}

\section{1 individual: a hero who save people}

The society in The Long Goodbye has been thoroughly corrupt, that is why the performance of the characters in the novel is often incredible: the real power of the state, the defenders of justice, in order to maintain the seeming justice, deceive the masses, only to protect the interests of the class they represent. They make wrongful convictions and confuse right and wrong. Instead, the detectives who wander between justice and profit are often cynical, both good and evil, weary and sad in the gray areas of the city. The city's spokesmen survive under the aegis of corrupt police, who treat those they consider inferior from above. Detectives criticize the corruption of urban society and the decadence of the modern world, but their power is limited. They risk their lives for justice, but they always get hurt. In this day and age, real criminals go free from the law and innocent suspects are put in prison. Marlowe is locked up in this sort of isolation, where incompetent police pour coffee on him, wring his neck and nearly crack his artery. These law enforcement officers are like a destruction squad armed with lethal weapons, harming people at will until they get a satisfactory answer. Detective Green told Marlowe bluntly, "I've been a cop a long time and one thingI've learned for sure is it ain't always what you do that gets you sent up. It's what it can be made to look like when it comes into court.(Chandler, Raymond. The Long Goodbye[M]. New York:Knopf,2002)". It is the guardians of these cities who have played with the law and made arbitrary judgments that have led to the country's moral decline. These are hints that the vitality of the traditional American spirit has been lost in the development of the country. Thus, in the novel, Chandler criticizes the existing social order through his dissatisfaction with the hierarchical society. The government and the criminals conspire to make huge profits, and it is the little people who suffer the most, the fools who want to get something for nothing. From the classical detective novel to the hard-boiled detective novel, the continuous corruption of the social order also exists a short development process. In Christie's novel, social order is broken, but eventually it has to be restored. But the society in Chandler's novels has entered the stage of total corruption, and the murders involved in the novels are often related, one murder after another. Behind every murder, there is a lot of crime, a lot of conspiracy, and even a body after being murdered in various ways. Almost everyone in the book will be involved in the case, but Marlowe is an outsider, he is innocent, he himself will not have anything to do with the case, he is like an objective existence, forever dissociated from the case. He had no wife or lover, no private life except the necessities of food, clothing, and sleep.

We can see heroism in Marlowe. The existence of Marlowe is an indispensable ray of light in the dark society. 
He exposed the dark side of society to the world, and with his own small power to change all this. He was often hurt and threatened, but when he faced darkness again, he would still stand up and fight for justice and for the society regardless of his own safety. He is cynical, which is just what the society needs.

He moved between the upper and lower classes, but he was always kind to the weak. He is not only helping people but also helping to rebuild the moral order of American society. Unable to bear the darkness, he put all his efforts into searching for the light.

\subsection{Society: a product of the current environment}

As a private investigator, Marlowe is brave and lonely. For professional reasons, his personal life is monotonous, and no one understood him. Everyone is a product of a particular social environment, and his personality is closely related to the social environment. The spiritual outlook of a society can greatly influences one's character. Therefore, all aspects of Marlowe's characters have their social roots.

As mentioned earlier, Marlowe had a lonely soul. His loneliness manifests itself in every aspect of his life. In solving crimes, he pursued justice alone. At home, his only recreation was chess. He is not in love because he thinks women often cause trouble. He has fewer and fewer friends. In the face of the dark forces, he always alone to defend the justice of his heart.

Loneliness was a common disorder in the United States during this period. Due to the rapid development of capitalism, everyone was divided into different individuals. The forces of justice were scattered, but the forces of darkness rose against them. The weak power of individuals is far less than the control of the dark groups in society, so fairness and justice are beyond the reach of the general public. The Marlowes tried to become knights of the city and save the masses, but because of the limited number, they had to give up. Nothingness is the symbol of the whole city. In this period, the efforts of individuals and groups failed to change the whole society. People leave the battlefield of real life and return home to the battlefield of morality. The battle is harder, and the enemy is stronger. The people who control the city become the spokesmen of the black forces and the law enforcers become the accomplices of the crimes. The ordinary people in the plight of suffering, struggling to survive, and the knights of the city to change the status quo, by all kinds of obstacles and even life threats. Loneliness is the greatest enemy the knights face. They are often isolated and helpless, so, for a variety of reasons, they ultimately choose to compromise. Nothingness has planted a seed in everyone from the very beginning, and the emergence of hope is always accompanied by doubt. People no longer trust each other, loneliness is a personal carnival, after the carnival, nothingness becomes the outcome of all efforts.

Marlowe's tough guy image is not innate but driven by the environment. He was not born brave but learned to fight back with violence in a violent environment. In The Long Goodbye, people have either become accustomed to violence against others, or they choose to help the wicked perpetuate wicked deeds, or they can only allow the violence to persecute and have no power to fight back.

The most immediate effect of the violence is the fear of deception, and when it comes, civilians are powerless. The government uses political violence to rule the people. The violence of the underworld is everywhere. When violence is everywhere, people are in a state of panic and lose the ability to resist. Apart from its rulers and perpetrators, everyone seems to be in the shadow of violence. Even Marlowe, who have greater viability than the ordinary people, often subjected to violent threats. If his investigation process accidentally threatened the interests of the upper class, he will be taken to someplace to suffer the violence. The policemen were not polite to him. They were entrusted to warn Marlowe not to make trouble for himself. The violence hung over Los Angeles like an invisible net.

Therefore, the tough guy image was actually developed by Marlowe in order to protect himself. He is no different from ordinary people, just a little stronger than ordinary people, more able to withstand the threat of the dark forces. He has his own ideals and beliefs, can stand up for the pursuit of truth, but often alone struggle, alone against this evil society. He is upright and takes the pursuit of justice as his duty. In all his actions, we can see that there was an indomitable character, an imperturbability of mood, and a cold, hard determination.

In 1929, the world economic crisis broke out after the World War I. The society was in chaos and the people were in a panic. The economic index continued to decline. The government lost its dominant control over the city, and the underworld terrorized the whole society. Traditional decent people collude with underworld forces and criminals. The whole social order is in a state of collapse, crimes are being committed, and the traditional moral tower is collapsing. American society advocates "individualism". At this time, a savior is needed to save the world. So people like Marlowe are needed. He is indeed a product of the current social environment, because with darkness, there must be light.

All in all, Marlowe is a character who bears great responsibility to the society and who does not abandon the pursuit of justice. He was never afraid of being stigmatized 
and thrown into prison, because in his mind he was his own judge.

\section{CONCLUSION}

The image of tough guy has attracted much attention in the history of foreign literature. The literary phenomenon is the best reflection of the background of this period. Marlowe is a miracle that Raymond Chandler created. And in chandler's novel, he himself is Marlowe's ideal in the face of physical and psychological threats. And this is an ideal that Marlowe would like to have, and it doesn't feel stiff in him. Raymond chandler's life is during the two world wars, he has witnessed a division and rebirth of the world. The two world wars destroyed the stable pattern of the world should have and destroyed the human spiritual beliefs and values. So many disasters and tragedies were emerged and magnified in the war. The violence of the war, the fear for death and the feeling of nothingness gave Chandler indelible memories. We can see on his body the time brand mark. Hemingway also experienced the spiritual impact and shock brought by the war, so he determines to use his pen as a weapon to declare war against the dark society, for the "tough guys".

Chandler once said that any kind of novel should be realistic. Unfortunately, some writers, who set out with a sense of realism, produce works that feeling disguised and artificial for realism's sake. Chandler's novel is not only a template for tough guy novels, but also an object for realistic writers to imitate. "Nothingness" is his overall perception of his life, and he placed all his life ideals on Marlowe. He wants to meet his pursuit of "tough guy" through Marlowe's adventure.His life was not very happy, and there was no hope for the future, so he killed himself in a cowardly way. But once he started writing about Marlowe, he had a new hope. In his eyes, Marlowe is a tough guy, a tender and sympathetic detective, a noble and brave knight.

Today, we live a long time after Raymond chandler's time, but his influence on literary creation remains. Raymond Chandler used most of his time to looking for tough guy. In the face of the world of emptiness and despair, he creates his own "tough guy", and creates a hard-boiled detectivePhilip Marlowe with a golden heart. This is the hope of Chandler, and also the hope of the whole world.

In the 1920s, the tough guy image always played an important role in literature. With the arrival of the new era, human beings entered a relatively peaceful era. people's life become plain, but people become more and more cowardly. We need tough guys like Marlowe in our society, who are not afraid of facingauthorities, do not flinch from difficulties, and go forward when facing with challenges.
The return of the tough guy is especially important. Academically, we still have a long way to go in the study of tough guys. In social life, we should also learn from tough guys and integrate their spirit into the spirit of our times.

\section{REFERENCES}

[1] A. Mary Murphy. Creatures of Darkness: Raymond Chandler, Detective Fiction, and Film Noir by Gene D. Phillips (review)[J]. Rocky Mountain Review of Language and Literature,2001,55(1).

[2] Chandler, Raymond. The Long Goodbye[M]. New York:Knopf,2002.

[3] Joseph Navitsky. Raymond Chandler and the Art of the "Shakespearean Touch"[J].TheJournal of American Culture, 2014,37(2).

[4] Luo Ting. Introduction to the Hard-Boiled Detective Fiction of Raymond Chandler[D].Shannxi Normal University,2015.

[5] Rachel Watson. Fredric Jameson, Raymond Chandler: The Detections of Totality[J]. ,2018,44(4).

[6] STEFANO TANI. Raymond Chandler's Philip Marlowe: The Hard-BoiledDetective Transformed[J]. Cambridge University Press,2013,47(1).

[7] Susan Peck MacDonald. Chandler's American Style[J]. Pennsylvania State University Press,2005,39(4).

[8] Tamara Slankard. Modernist Hollywood: Place Attachment in Raymond Chandler's The Little Sister[J]. Journal of the Midwest Modern Language Association,2016,48(2).

[9] Transcending noir - Claire Grove's BBC radio adaptations of Raymond Chandler[J]. Journal of Adaptation in Film \& Performance, 2015,8(2).

[10] Wang Zhenping. The Spirit of Hard-boiled Detective: Raymond Chandler [J].World Cunture,2008(09):15-17.

[11] Zhang Jing. Raymond Chandler and The Long Goodbye[J].Chinese Book Review Monthly, 2014 (03):92-94. 